\title{
Transformasi Dampak Krisis Ekonomi ke Krisis Lingkungan Binaan oleh Sektor Informal
}

\author{
Sardjito $^{1}$ \\ ${ }^{1}$ Urban and Regional Planning Department, Institut Teknologi Sepuluh Nopember, Indonesia
}

\begin{abstract}
ABSTRAK
Keberadaan Pedagang Kaki Lima (PKL) cenderung diassumsikan sebagai bentuk manifestasi dari "kemiskinan" dalam kawasan perkotaan. Keberadaan Pedagang Kaki Lima (PKL) memiliki dampak negatif sekaligus dampak positif yang relatif seimbang pengaruhnya terhadap kehidupan perkotaan, hal ini menjadi suatu justifikasi bahwa eksistensi PKL perlu dipertahankan. Untuk itu perlu pemahaman karakteristik PKL guna menata para PKL. Dalam studi identifikasi karakteristik PKL, penulis mencoba mengeksploitasi permasalahan kota yang dibangkitkan (generated) oleh sektor informal khususnya Pedagang Kaki Lima, bahwa telah terjadi suatu pergeseran "paradigma" pandangan terhadap keberadaan PKL, dimana perspektif "dulu" berpandangan bahwa keberadaan PKL sebagai reaksi dari keterpurukan dalam aspek ekonomi yang berbuntut menjamurnya "Sektor Informal", anggapan yang tumbuh "sekarang" ini adalah bahwa sektor informal telah dianggap sebagai "katup penyelamat" Akan tetapi anggapan tersebut masih perlu dilakukan pengkajian ulang (redifine) dalam memandang PKL, untuk itu tujuan penulisan ini adalah melakukan identifikasi terhadap perubahan sudut pandang para pelaku sektor informal, khususnya PKL dari kegiatan yang sifatnya sementara (temporary) menjadi kegiatan yang menjanjikan keberadaannya (permanent) yang akhirnya berpengaruh terhadap lingkungan binaan di perkotaan.

Dalam melakukan identifikasi karakteristik PKL, menggunakan metode pendekatan kualitatif. Data diperoleh melalui teknik wawancara terhadap stakeholders PKL, khususnya terhadap pelaku (pedagang) PKL, kemudian diinterpretasikan untuk dipaparkan secara kualitatif, guna memahami karakteristik kegiatan PKL di wilayah penelitian

Hasil studi teridentifikasikan bahwa PKL sebagai suatu "proses" yang dapat menyebabkan terjadinya krisis baru, dimana perubahan (transformasi) PKL sebagai pekerjaan yang bersifat sementara untuk bertahan hidup (survive), beralih ke pembentukan komunitas PKL yang mempunyai kekuatan bersifat latent (hidden power) yang kemudian melakukan "pembenaran" (justification) eksistensi mereka kedalam bentuk "permanen" yang pada akhirnya berimplikasi kepada krisis lingkungan binaan di dalam kawasan kota. Krisis lingkungan antara lain terhadap estetika kota, lingkungan binaan, hak atas lahan, kemacetan lalu lintas sebagai dampak yang ditimbulkan (eksternalitas) dari keberadaan PKL. Oleh karena itu dalam memandang kegiatan PKL, perlu dilihat lebih arif dan bijaksana, bahwa keberadaan PKL sebagai sektor informal perlu penanganan yang khusus, bukan hanya dipandang sebagai sekedar sektor "Informal" tetapi juga sebagai bentuk kegiatan "Formal" yang mampu berpengaruh pada lingkungan binaan
\end{abstract}

Kata Kunci : PKL, Krisis Lingkungan 


\section{PENDAHULUAN}

\section{Sektor Informal}

Faktor tolakan dari desa (rural push factor) jelas merupakan penjelasan yang baik guna menjawab pertanyaan: mengapa terjadi proses urbanisasi di banyak negara sedang berkembang ?". Assumsi bahwa proses urbanisasi di kota negara sedang berkembang terjadi karena para migran pedesaan telah "tertolak" dan bukannya "tertarik" ke daerah perkotaan, assumsi yang demikian ternyata terbalik, bahwa perkotaan di negara sedang berkembang ternyata memiliki daya tarik bagi migran pedesaan. Kemudian yang menjadi pertanyaan adalah: mengapa kota di negeri berkembang begitu menarik buat penduduk pedesaan ?"

Pertama tentunya perlu diingat bahwa telah terjadi deferensiasi pendapat an antara desa dan kota. Gambaran tersebut sudah cukup untuk memberikan penjelasan pertama dalam hal mengapa daya serap kota begitu kuat. Kaum migran dari pedesaan tertolak kuat untuk bermigrasi ke kota disebabkan oleh tekanan penduduk di daerah pedesaan. Seberapapun besarnya tekanan penduduk di daerah-daerah pedesaan, hal ini tak akan cukup kuat untuk menghalau penduduk pedesaan dari desanya kalau mereka tidak tahu bahwa kesempatan kerja yang lebih baik tersedia di luar pedesaan mereka. Dengan kata lain, mereka pindah ke kota karena "dalam lotere kehidupan, kemungkinan untuk memperoleh sedikit keberhasilan jelas lebih besar di kota", demikian Friedman dan Lackington.

Para ahli yang bekerja di International Labor Office (ILO) telah mengajukan model struktur ekonomi dualisme di negara berkembang. Mereka membedakan antara "sektor informal" dan "sektor formal". Istilah sektor formal dan sektor informal juga telah diintrodusir oleh Keith Hart dari University of Manchester.

\section{Pedagang Kaki Lima}

"Sektor informal" yang bergerak di daerah perkotaan di Indonesia, menurut jenisnya, salah satunya adalah Pedagang Kaki Lima (PKL). Secara umum pedagang kaki lima dapat diartikan sebagai pedagang kecil yang pada permulaannya mempunyai peranan sebagai penyalur barang dan jasa ekonomi perkotaan (Tb. M. Rais), atau dengan kata lain pedagang kaki lima termasuk pedagang eceran yang bermodal kecil yang berpendapatan rendah dan berjualan ditempat-tempat umum, seperti di kaki lima, diemperan toko, ditepi jalan raya, taman, pasar, tanpa ijin usaha dari pemerintah.

Pedagang kaki lima (PKL) merupakan fenomena yang lazim ditemui di perkotaan negara berkembang seperti halnya di Indonesia. Area-area strategis perkotaan seperti pusat kota, trotoar sepanjang jalan besar, dan ruang publik yang ramai dilewati orang menjadi pilihan PKL untuk mengembangkan usahanya. PKL memberikan kontribusi yang cukup besar terhadap perekonomi an perkotaan dan merupakan "katup pengaman" bagi perekonomian masyarakat golongan ekonomi menengah ke bawah.

\section{Perumusan Masalah}

Bahwa keberadaan PKL perlu dipertahankan, dengan prasyarat utama yaitu dilakukan suatu upaya minimalisasi dampak negatifnya. Dengan demikian, yang perlu dilakukan adalah menertibkan para PKL tersebut, sehingga fungsinya dalam aspek ekonomi tetap berjalan, namun tidak memberikan ekses negatif terhadap kualitas ruang

Perkembangan PKL yang demikian pesat, bukannya tidak diiringi oleh upaya penanganannya. Berbagai bentuk kebijakan dalam rangka menangani PKL telah diinisiasi (digagas) oleh pemerintah. Tujuan pelaksanaan penataan adalah untuk ketertiban bersama, sehingga konflik antar kegiatan dapat diredam atau dapat dihindari.

Banyaknya komunitas pelaku PKL telah membuat gejala perubahan yang 
cukup signifikan, dimana proses timbulnya sektor informal bukan hanya sebagai alasan untuk tetap bertahan hidup (survive) dari sulitnya ekonomi di perkotaan, namun beralih kepada kekuatan yang sifatnya tersembunyi (hidden power), karena banyaknya jumlah mereka. Fenomena lainnya adalah adanya kecenderungan untuk hidup yang layak, dalam bentuk pengambil alihan lahan yang mereka tempati, baik itu lahan kosong (vacant land) atau lahan yang telah jelas peruntukannya. Dalam hal lokasi yang mereka tempati, kegiatan PKL cenderung menimbulkan konflik baik kemacetan, kekumuhan, dan estetika kota.

\section{Tujuan}

Tujuan penulisan ini adalah melakukan identifikasi terhadap perubahan sudut pandang para pelaku sektor informal khususnya PKL dari kegiatan yang sifatnya sementara (temporary), menjadi kegiatan yang menjanjikan keberadaannya (permanent) yang akhirnya berpengaruh terhadap lingkungan binaan di perkotaan.

\section{Ruang Lingkup Wilayah}

Ruang wilayah studi adalah wilayah Kota Surabaya, secara adminsitrasi terdiri atas 31 kecamatan dan 163 kelurahan relatif cukup luas dengan jumlah PKL yang banyak.

\section{KAJIAN PUSTAKA}

Urip Suwarno serta Hidayat mengemukakan ciri-ciri sektor informal, antara lain :

1) Aktifitas pada sektor ini tidak terorganisisr secara baik, karena timbulnya tidak melalui institusi yang ada pada perekonomian modern

2) Pada umunya setiap unit usaha tidak mempunyai ijin usaha dari pemerintah

3) Pola kegiatannya tidak teratur dalam arti tempat maupun jam kerja

4) Unit usaha pada sektor ini mudah untuk keluar dan masuk dari satu sektor-kesektor lainnya

5) Tidak diperlukan tingkat pendidikan tertentu. Bahkan keahliannya didapat dari sistem pendidikan non formal dan pengalaman.

6) Kebanyakan unit usaha termasuk kedalam one-man enterprise, ataupun kalau mempunyai buruh, maka buruh tersebut berasal dari lingkungan keluarganya dan unit usaha tersebut dinamakan family enterprise

7) Hasil produksi dan jasa dari sektor ini terutama sekali dikonsumsi oleh golongan masyarakat miskin dan kadang-kadang oleh golongan menengah.

\section{Pedagang Kaki Lima}

Pada awalnya pedagang melakukan kegiatan berdagang guna meningkatkan taraf hidupnya (Harris \& Sabot), Salah satu karakteristik tersebut merupakan dominasi pada saat sebelum terjadi krisis ekonomi, sedangkan sesudah krisis ekonomi terjadi pergeseran, yaitu munculnya kombinasi korban PHK dan angkatan kerja baru yang sulit menembus sektor formal. Pada definisi Haris \& Sabot tersebut, PKL merupakan salah satu bentuk sektor informal.

Pengertian pedagang informal termasuk PKL, sebagaimana yang dirumuskan dalam keputusan bersama Menteri Dalam Negeri dan Menteri Koperasi dan Pembinaan Pengusaha Kecil Nomor 88 tahun 1997, No. 01/SKB/M/VI/1997, tentang Pembinaan dan Pengembangan Koperasi dan Pengusaha Kecil dalam Pengembangan Pasar dan Pertokoan, bahwa pedagang informal adalah pedagang usaha kecil dan atau penjual jasa yang berusaha dengan menggunakan tempat usahanya dipinggir jalan, fasilitas umum, tidak menetap, tidak mendaftar, tidak tercatat dan umumnya tidak memiliki badan hukum. Atau sektor usaha informal yaitu sektor kegiatan usaha yang bersifat tidak menetap, tidak memiliki surat ijin pendukung dengan atau tanpa bangunan didirikan pada fasilitas umum, sosial, atau persil/ bangunan pribadi baik usaha jasa perdagangan, jasa, maupun industri. 
Berdasarkan pengertian PKL tersebut, definisi PKL yang dipergunakan dalam penelitian ini adalah berkaitan dengan lingkup wilayah yang di teliti adalah pedagang yang berjualan di ruas jalan, trotoar/ berm, taman, areal parkir. Pedagang tersebut terdiri atas pedagang yang menggunakan sarana berdagang permanen (menggunakan kios dan atau lantai permanen), semi permanen (menggunakan lapak atau meja kayu/besi) dan non permanen (menggunakan gerobak). Berdasarkan lingkup wilayah tersebut, maka PKL yang menjadi obyek penelitian adalah PKL dengan sarana berdagang semi dan non-permanen.

Kekhasan tempat berdagang menjadi bagian dari definisi PKL dan merupakan salah satu karakteristik fisik. Dalam memanfaatkan ruang PKL cenderung :

> Memanfaatkan jalur pedestrian dan badan jalan dengan sarana berdagang berdiri bebas, atau dipatok pada dinding pagar

$>$ Memanfaatkan ruang publik dengan fungsi tempat berdagang sekaligus fungsi penyimpanan sarana berdagang

> Tidak melakukan bergiliran dengan PKL lain yang menunjukan "kepemilikan" lahan yang ditempati

$>$ Tidak mau berpindah dari lahan yang ditempati dan berhasrat untuk tetap menguasai ruang/lahan tersebut sepanjang memungkinkan. Hal ini diperkuat dengan keputusan untuk tetap bekerja sebagai PKL karena merasa pengha-silannya telah cukup memenuhi kebutuhan dasar dan merasa aman karena telah membayar retribusi.

Pelaku PKL menjajakan barang dagangannya biasanya menempati ruang publik, menurut Hamid Shirvani (1981), ruang publik merupakan keseluruhan landscape dan hardscape (jalan, trotoar, dan materi sejenisnya), taman-taman, dan tempat rekreasi dalam lahan kota yang bersifat publik. Ruang publik juga didefinisikan sebagai lahan tidak terbangun di dalam kota dengan penggunaan tertentu. Ruang publik merupakan tempat masyarakat melakukan pergerakan, komunikasi dan tempat yang memberikan kesempatan untuk relaksasi.

$>$ Secara sosiologis, kelompok PKL bersifat paguyuban (geimenschaft), artinya antara PKL yang satu dengan lainnya memiliki hubungan, baik keluarga, teman sedaerah maupun satu kelompok dari grosir mata dagangan (komoditas) yang sama. Sifat informalitas PKL dan juga label ilegal yang disandangnya, merupakan motif yang cukup kuat untuk membina hubungan baik antar anggota komunitas. Hal ini secara akomulatif menimbulkan perilaku politis PKL, sebagai sebuah sikap bersama untuk menyelesaikan permasalahan lisensi keberadaan PKL secara kolektif.

Perilaku politis tersebut merupakan akumulasi hasil pengalaman kolektif yang berkulminasi dalam sangsi-sangsi yang selama ini diterima ketika PKL berhadapan dengan aparat pemerintah, pemilik toko serta masyarakat pengguna lainnya. Perilaku politis PKL tersebut menyebabkan transedensi dari survival (kegiatan PKL sebagai alternatif bagi masyarakat marginal keluar dari krisis ekonomi). Menjadi hidden power yang menjadikan PKL sebagai bidang kerja tersendiri yang banyak diminati dan terus berkembang. Kondisi ini praktis menimbulkan ekskalasi kegiatan dari non permanen menjadi permanen di lihat dari adanya aglomerasi kegiatan PKL dalam pola penempatan dan penyebaran PKL serta sarana berdagang yang tidak lagi sesuatu "sekedarnya". Evolusi ini dapat dikatakan sebagai imunisasi krisis ekonomi ke krisis lingkungan binaan yang membuat semakin sulit untuk membenahi keadaan.

Perilaku politis tersebut juga dilakukan oleh pihak luar PKL yang cenderung mempertahankan informalitas PKL, baik pemerintah maupun masyarakat. Perilaku politis yang bersifat memfasilitasi 
kegiatan PKL sekaligus melemahkan posisi PKL berupa pemberian kesempatan kepada PKL untuk melakukan "penyogokan" dan "penyuapan" kepada pemerintah melalui perantara seringkali dilakukan. Selain itu terjadi fenomena jual beli lapak yang dilakukan oleh makelar ataupun oknum pemerintah sendiri. Sementara kebutuhan dan kultur masyarakat yang menempatkan PKL sebagai tujuan utama kegiatan konsumsi dengan segala nilai tambah sebagai akibat informalitas PKL tersebut, semakin memperkuat eksistensi PKL. PKL juga menjadi format pedagang yang di incar oleh pedagang besar atau pengusaha sebagai bentuk penghidaran pajak. Oleh masyarakat, PKL dipertahankan informalitasnya. Hal ini dinilai dari fakta bahwa peningkatan kesejahteraan PKL tidak menjamin mekanisme penjualan dengan sarana berdagang berupa lapak di ruang publik ditinggalkan dan di ganti dengan kios formal. Kecenderungan PKL memanfaatkan ruang publik dan menggunakan lapak tersebut dimanfaatkan pula oleh oknum-oknum di lapangan dengan memfasilitasi pengadaan lapak.

Kondisi kontradiktif di lapangan, dimanfaatkan secara produktif oleh masing-masing pelaku untuk mengedepankan kepentingan masingmasing. Hal ini menimbulkan sikap inkonsistensi, sehingga pemecahan masalah PKL semakin rumit akibat rawannya konflik. Dalam hal ini PKL merupakan satu-satunya pelaku yang berhadapan langsung dengan kepentingan dan keinginan pihak lain baik positip maupun negatip.

\section{METODE}

Pada dasarnya studi ini dilakukan melalui dua pendekatan, yaitu pendekatan teoritis dan pendekatan empiris. Pendekatan teoritis dilakukan melalui studi kepustakaan, sedangkan pendekatan empiris dilakukan dengan mencermati pemikiran manusia mengenai pandangan, saran dan harapannya (responden) yang dalam hal ini pelaku PKL. Studi kepustakaan bertujuan untuk menghasilkan kerangka dasar pemahaman teoritis yang menjadi pijakan dasar dalam penelitian ini. Berdasarkan pendekatan teoritis ini, menghasilkan pengertian dan pemahaman secara umum tentang karakteristik/ciri kegiatan Pedagang Kaki Lima. Berdasarkan pemahaman tersebut kemudian disusun desain penelitian, baik berbentuk questioner maupun check list. Berdasarkan desain penelitan tersebut dilakukan kajian empiris. Pendekatan empiris bertujuan untuk melihat kondisi yang sebenarnya tentang pola kegiatan PKL. Penggalian karakteristik yang mewarnai kegiatan PKL di wilayah penelitian.

Eksplorasi variabel karakteristik kegiatan dilakukan terhadap responden sebagai perwakilan dari kelompok pelaku kegiatan yang telah teridentifikasi, melalui survai questioner. Tujuannya adalah mencari fenomena yang terjadi tanpa intervensi penulis, namun terarah tidak tanpa batasan.

Survei dilakukan melalui dua pendekatan, pertama untuk dilakukan dengan menyebar questionair, kedua akan dilakukan wawancara dengan responden. Untuk penyebaran Questionary (sebagai survei awalnya), dilakukan penetapan jumlah responden berdasarkan persebaran jumlah PKL di kawasan penelitian (dengan probabilitas antara $60-85 \%$ ). Jumlah renponden berdasarkan hasil perhitungan sebanyak 290 responden. Untuk wawancara, dari penetapan wilayah penelitian reponden dipilih secara random, selain itu juga dilakukan dengan menggunakan metode wawancara semi tertutup (semi terstruktur). Informasi juga diperoleh dari hasil observasi penulis, wawancara semi tertutup (semi terstruktur) dan juga pengamatan perkembangan kegiatan di wilayah penelitian. 
HASIL

\section{Gambaran Umum Pedagang Kaki Lima (PKL) di wilayah Studi}

Wilayah Kota Surabaya tercatat seluas 29.249 Ha, secara administrasi terbagi adalam 31 Kecamatan 163 Kelurahan. Pada Tahun 2015 jumlah penduduk mencapai $\pm 3,1$ juta jiwa. Peranan sektor perdagangan dalam pertumbuhan ekonomi kota Surabaya cukup besar, hal ini terlihat dari komposisi kontribrusi sektor Perdagangan terhadap Produk Domistik Regional Brutto (PDRB) berdasarkan harga konstan.

Dari data hasil observasi menunjukan, bahwa Kegiatan Pedagang Kaki Lima tersebar hampir di seluruh jalan maupun ruang publik lainnya di wilayah Kota Surabaya. Lokasi kegiatan PKL pada umumnya menempati lokasi yang di nilai strategis, seperti di jalan umum, trotoar, ruang publik (alon-alon), sekitar pasar tradisional, di atas riol/gorong-gorong/ saluran drainase, serta kawasan-kawasan yang banyak dikunjungi orang (misalnya rumah sakit, sekolahan, Mesjid di hari jumat, kantor pemerintah, lokasi proyek pembangunan).

Bila dirunut lebih jauh, karena adanya krisis ekonomi, berakibat kegiatan pedagang kaki lima berkembang cukup pesat. Para pelaku PKL di lihat dari tingkat pendidikannya, memberi gambaran bahwa pelaku PKL ada yang berpendidikan Sekolah Dasar, pelaku lulusan Sekolah Dasar pada umumnya pelaku yang sudah lanjut usia. Kemudian PKL yang berpendidikan Sekolah Lanjutan Tingkat Pertama. lulusan SMU/sederajat dan ada juga PKL yang berpendidikan sampai ke perguruan tinggi. Pada umumnya PKL yang berpendidikan SMU dan lulusan ataupun putusan Perguruan Tinggi justru relatif masih muda. Berdasarkan informasi, mereka yang berpendidikan cukup tinggi berdagang karena korban PHK.

Sebagian besar pedagang kaki lima berasal dari luar kota Surabaya, seperti dari Lamongan, Jombang, Bangkalan,
Sidoarjo, wilayah jawa tengah dan jawa barat, bahkan ada yang kelahiran Pekanbaru memiliki keluarga di Tulungagung.

Dari wawancara dengan responden, memberikan informasi sejarah perjalanan berjualannya, pada awalnya banyak di antara mereka berjualan barang pemenuhan kebutuhan sehari-hari, seperti bahan makanan/minuman, namun ternyata pengunjung kurang berminat, kemudian berubah berjualan pakaian, ternyata pengunjung juga kurang berminat, terakhir banyak yang berjualan barang hasil industri yang kecil-kecil, seperti sepatu, sandal, tas, radio, kacamata. Selain alasan kurang diminati pengunjung, mereka juga mencari barang dagangan yang mudah/praktis membawanya, hal ini berkaitan dengan waktu berjualan (sore hari) serta alat peraganya yang harus dibenahi setelah berjualan (alat peraganya ternyata banyak yang "dititipkan" dekat kawasan berjualan, tidak dibawa pulang). Di kawasan layanan umum (sekolah, Rumah sakit) pada umumnya berjualan makanan dan minuman.

\section{Karakteristik PKL di Kota Surabaya}

Berikut ini karakteristik Pedagang Kaki Lima (PKL) di Kota Surabaya berdasarkan hasil survei melalui wawancara, sifatnya semi tertutup dengan menggunakan check list dan penyebaran questionert.

1) Awal memulai kegiatan menjadi PKL bahwa banyak PKL yang memulai usahanya sejak tahun 2000 (66,5\%), sejak setelah adanya krisis ekonomi, Pelaku kegiatan pada umumnya merupakan generasi ke dua (melanjutkan kegiatan orang tuanya). Untuk yang memulai sejak tahun 2013 sebesar 9,89\%, umumnya berlokasi di kawasan baru (perumahan baru, gedung pusat kegiatan baru)

\section{2) Tempat asal PKL}

bahwa PKL yang asli dari Surabaya hanya $14 \%$, terbanyak dari luar Surabaya namun masih di lingkungan wilayah Gerbangkertosusila (54\%), luar Gerbangkertosusila masih di lingkungan 
Jawa Timur ( $16 \%$ ), sisanya dari luar Jawa Timur masih di Pulau Jawa dan ada yang dari luar Pulau Jawa.

\section{3) Kisaran pendapatan PKL perbulan}

Berdasarkan pengalaman penjual nasi (sebagai responden) yang melayani pegawai pertokoan (formal), kebanyakan pembeli melakukan transaksi dengan mengutang ("ngebon") terlebih dahulu, setelah pembeli memperoleh "gaji" baru membayar. Rata-rata omzetnya perhari antara 230 - 450 ribu rupiah perharinya, bila dikurangi modalnya, maka keuntungannya antara 95 - 350 ribu rupiah perharinya. Rentang pendapatan PKL terbanyak ( $24 \%$ ) berkisar antara $2-5$ juta perbulannya.

4) Kisaran pengeluaran kebutuhan dasar perbulan

Kisaran pengeluaran kebutuhan dasar PKL perbulannya kurang dari $40 \%$ pengeluaran perbulannya mencapai 2.5 juta rupiah, selebihnya lebih dari 2,5 juta rupiah.

\section{5) Kisaran biaya pemeliharaan sarana berdagang PKL}

Kisaran pemeliharaan sarana untuk berdagang PKL (untuk tempatnya) kurang dari 350.ribu rupiah (20 \%) selebihnya tidak diketahui (tidak menjawab), ini menunjukan bahwa pedagang tidak memiliki angka pemeliharaan sarana berdagangnya yang rutin, umumnya pemeliharaan dilakukan kalau rusak baru diperbaiki.

\section{6) Keputusan menetap di lahan/lokasi yang ditempati}

Keinginan PKL untuk tetap menetap pada lahan/lokasi yang ditempati cukup besar $(58,4 \%)$, umumnya beralasan, bahwa untuk memperoleh lahan tersebut tidak mudah (tidak gratis).

7) Keputusan untuk pindah dari lahan/lokasi yang ditempati

Keinginan untuk mau pindah (apabila harus pindah) relatif kecil $(12,8 \%)$, keinginan untuk pindah ini dikarenakan adanya kesadaran, atau sudah memperoleh lahan/lokasi baru yang lebih menguntungkan

\section{8) Keputusan untuk tetap menjadi PKL walaupun harus pindah \\ Dari yang harus pindah, meskipun} dipindah, ternyata ada yang masih ingin tetap berprofesi sebagai PKL $(28,26 \%)$, namun sebagian besar tidak menjawab

9) Cara menyimpan barang di lokasi berdagangnya

Sebagian besar PKL (47,15 \%) menyimpan barang dagangannya di kios tempat berdagangnya, (karena tidak memiliki tempat penyimpanan khusus/gudang), apabila penuh, maka barang dagangannya ditaruh ditepi jalan.

10) Sistem pergantian lahan/ruang yang dikuasai

Sistem pergantian penggunaan kios antar pedagang PKL di lokasi yang sama hampir tidak terjadi, karena penempatannya "sudah diatur", dan seolah lokasi tersebut menjadi "haknya".

11) Kecukupan memenuhi kebutuhan dasar

Rata-rata pedagang PKL (63\%) menyatakan terpenuhi kebutuhan dasarnya, seperti kecukupan makan, tempat tinggal (kos).

12) Presistensi terhadap usaha dan lokasi

Presistensi untuk tetap bertahan sebagai pedagang PKL beraneka ragam pendapatnya, $5.2 \%$ menyatakan ganti usaha lokasi tetap, 2,2 \% ganti lokasi usaha tetap, 12,8\% usaha dan lokasi tetap, selebihnya tidak menjawab

\section{3) Presistensi terhadap lokasi dan} usaha

Keputusan ganti usaha $(9,1 \%)$, Buka cabang (16,3\%), usaha dan tempat tetap $(40,86 \%)$ dan tidak menjawab $33,9 \%$ )

14) Keputusn membawa kios bila harus pindah

Perlakuan terhadap kios bila harus pindah, ternyata $56 \%$ menyatakan untuk dibawa dan atau dijual.

\section{5) Alasan sikap bertahan}

Alasan PKL untuk akan tetap bertahan di lokasi yang "telah dikuasai", karena merasa telah membayar "ijin 
lokasi" dan "retribusi" (meskipun tidak jelas ke siapa?)

\section{6) Pemakaian lahan/kios sebagai} ruang hunian

Sebagian besar PKL menyatakan bahwa kios hanya untuk berdagang, namun ada yang menyatakan sekaligus sebagai hunian $(14,9 \%)$.

\section{7) Durasi pemakaian ruang}

Sebagian besar berjualan pada sore hari, mulai dari jam 17.00 - 22.00, namun ada yang berjualan dari pagi sampai siang, kemudian dari sore sampai malam hari. Tergantung dari banyaknya pejalan/calon konsumen yang melewatinya lokasinya.

\section{8) Elemen ruang jalan yang} dipergunakan

Sebagian besar menggunakan jalur pedestrian, kemudian berturut-turut, badan jalan, soil kerb, grass kerb, bagian taman kota/lingkungan, teras bangunan.

19) Posisi penempatan kios pada ruang kota

Posisi penempatan kios sebagian besar berdiri sendiri, kemudian ada yang dipatok didinding bangunan, diatas saluran, dibawah pohon, ditempat parkiran, di halaman bangunan formal, disepan pedagang formal.

20) Kecenderungan penggunaan jalan dengan lebar tertentu

Kecenderungan penggunaan lebar ruan jalan yang dipergunakan, rata-rata adalah $3-9$ meter

\section{1) Tipe jalan yang cenderung dipergunakan \\ Pada umumnya PKL tidak/kurang} memperhitungkan hirarkhi fungsi jalan, apakah arteri, kolektor atau lokal/lingkungan. Pertimbangannya hnya pada sisi keramaian calon konsumennya.

22) Kedalaman ruang jalan

Kedalaman ruang jalan yang dipergunakan untuk berjualan dan menyimpan barang sebagian besar berkisar antara $1.5-3$ meter

23) Bagian ruang jalan yang dipakai untuk berjualan

Pertimbangan lokasi yang strategis dari sisi bila berjualan menjadi pertimbangan utama bagi lakasi PKL. Sebagian besar (pada umumnya) di persimpangan jalan, namun demikian penggunaan semua jenis bagian jalan yang menguntungkan dipergunakan

\section{4) Barang Dagangan}

Pada umumnya barang yang diperdagangkan berupa makanan siap saji, kemudian barang hasil industri (alat dapur, sepatu, pakaian) dan jasa.

\section{5) Pengelompakan dan penyebaran lokasi PKL \\ Pada umumnya PKL berkelompok,} membentuk komunitas PKL pada suatu kawasan, namun demikian juga ada yang sendiri-sendiri sesuai dengan lokasi konsumennya

\section{6) Tipe Kios dan Perabot}

Sebagian besar menggunakan berbentuk gerobak dengan tenda, Rak dengan tenda, Kios dengan pondasi tanpa tenda, Kios dengan pondasi dengan tenda, gerobak dengan payung, tenda warnawarni (biasanya ada sponsor)

\section{7) Dimensi Kios}

Dimensi kios berkisar antara 4 - 30 meter persegi, sebagian besar berdimensi 4 -8 meter persegi

\section{BAHASAN}

\section{A. Identifikasi Pergeseran Krisis Ekonomi Ke Krisis Lingkungan Binaan Oleh Pedagang Kaki Lima di kota Surabaya}

Pilihan Pedagang Kaki Lima Sebagai Alternatif Masyarakat Marjinal Keluar Dari Krisis Ekonomi

Berdasarkan karakteristik PKL terhadap variabel, dan faktor Pedagang Kaki Lima Sebagai Alternatif Masyarakat Marjinal Keluar Dari Krisis Ekonomi. Memberikan beberapa indikasi:

1) Profesi sebagai PKL merupakan pilihan guna mengatasi krisis ekonomi

2) Sebagian besar pelaku PKL berasal dari wilayah hinterland Surabaya

3) Gambaran pendapatan dan pengeluaran PKL lebih dari cukup untuk bertahan hidup, Hal ini menunjukan bahwa PKL 
dapat memenuhi kebutuhan dasarnya dan memberikan gambaran akan kemampuan keuangan PKL

4) Minimnya pengeluaran guna pemeliharaan kios berpengaruh terhadap tidak terawatnya kios, lapak, Hal ini meberikan kesan kumuh

5) Gambaran, ternyata bahwa PKL tetap bertahan sebagai PKL dan menjadikan PKL sebagai lapangan kerjanya

6) Besarnya dimensi kios menunjukan adanya kecenderungan penguasaan lahan, hal lainnya bahwa adanya sikap untuk tetap menguasai lahan/ruang tempat berjualannya.

Berdasarkan indikasi tersebut memberikan gambaran bahwa predikat PKL sebagai masyarakat marjinal perlu dipertanyakan kembali, selama ini PKL diberi label sebagai kelompok marjinal, sehubungan dengan anggapan sifat tidak resmi (sektor informal) dan tidal "legal". Sebagian pihak beranggapan bahwa masyarakat di sektor informal identik dengan kekumuhan dan kemiskinan, atau marjinal dalam pengertian ketidak cukupan atas pemenuhan kebutuhan dasar. Dari hasil identifikasi PKL di wilayah Kota Surabaya terungkap bahwa marjinal dalam pengertian batas kemampuan bertahan hidup, sebahagian telah terlampaui dan bahkan telah ada usaha PKL yang tidak lagi sebagai usaha transisi, namun sudah dapat menjadi gantungan hidup, bahkan jaminan kehiadupan yang lebih baik dari rata-rata minimal penghasilan.

\section{Identifikasi Kecenderungan Semakin Kuatnya Eksistensi PKL}

Berdasarkan karakteristik PKL terhadap variabel, dan faktor Kecenderungan Semakin Kuatnya Eksistensi PKL.

Memberikan indikasi bahwa :

1) Profesi sebagai PKL merupakan pilihan lapangan kerjanya, guna mengatasi kesulitan ekonomi
2) Banyak responden yang menyatakan tidak mau pindah, Hal ini memberikan

3) Indikasi menggambarkan kuatnya keinginan untuk menguasai lahan/ruang

4) Keinginan besar untuk menetap di lahan yang di "kuasai

5) Profesi sebagai PKL merupakan jaminan hidup dan tetap merupakan pekerjaan yang menarik

6) Menunjukan tempat berdagang juga digunakan untuk fungsi penyimpanan, ketika kios penuh dengan barang penyimpanan dilakukan ditepi jalan

Kecenderungan semakin kuatnya eksistensi PKL, mereka bangga dengan pekerjaannya, cenderung bertahan dengan pekerjaannya sebagai PKL dan cenderung mempertahankan lahan/ruang yang dikuasainya sepanjang memungkinkan.

\section{B. Pergeseran dari bertahan} hidup "survive" ke kekuatan yang tersembu nyi "hidden power"

Berdasarkan karakteristik PKL terhadap variabel, dan faktor Pergeseran dari bertahan hidup "survive" ke kekuatan yang tersembunyi "hidden power"

Memberikan indikasi :

1) Dalam konteks pergeseran dimana rentang pendapatan merupakan indikasi adanya kemapanan dalam penghidupan mereka

2) Dalam konteks pergeseran dimana rentang pengeluaran merupakan indikasi adanya kemapanan dalam penghidupan mereka

3) Dalam konteks pergeseran dimana rentang biaya pemeliharaan merupakan indikasi adanya kemapanan dalam penghidupan mereka

4) Dalam konteks pergeseran dimana rentang pemenuhan kebutuhan merupakan indikasi adanya kemapanan dalam penghidupan mereka

5) Indikator adanya kekuatan untuk mempertahankan usaha dan lokasi sebagai PKL 
Terangkatnya dari posisi sekedar bertahan hidup sampai pada posisi mempunyai power dalam hal teritorial space.

\section{Perubahan Paradigma}

Berdasarkan karakteristik PKL terhadap variabel, dan faktor Perubahan Paradigma. Memberikan indikasi bahwa :

Perubahan paradigma terjadi dalam konteks pemikiran awal bahwa pekerjaan PKL sebagai hanya sekedar pertahanan sementara (temporery) namun akhirnya menjadi profesi yang menjanjikan.

Perubahan paradigma tentang usaha PKL terungkap, perlu "redifinisi" tentang usaha PKL dalam kaintannya dengan kemiskinan perkotaan. PKL memang pada awalnya merupakan salah satu alternatif usaha survive, tapi kini dapat dikatakan merupakan salah satu bidang kerja tersendiri yang banyak diminati.

Memperhatikan hal tersebut dan dengan mengingat kembali teori sektor informal sebagai "batu loncatan" kaum migran untuk bisa masuk ke sektor formal kenyataannya menunjukan bahwa ada sementara orang bekerja disektor informal khususnya PKL memang melakukan usaha di sektor informal PKL. Sektor ini memang benar-benar menjadi tumpuan pekerjaannya, hal ini mengingat bahwa pelaku untuk sampai waktu 10 tahun sudah cukup untuk disimpulkan bahwa dia memang bergerak disektor informal PKL, sebagai pedagang (PKL) bukan lagi menjadi pekerjaan sambilan.

\section{Usaha Untuk Bertahan dan Mengembangkan PKL}

Berdasarkan karakteristik PKL terhadap variabel, dan faktor Usaha Untuk Bertahan dan Mengembangkan PKL.

Memberikan indikasi:

1) Usaha untuk bertahan sebagai PKL baik secara profesi dan penguasaan ruang/space
2) Usaha untuk bertahan sebagai PKL baik secara profesi dan penguasaan ruang/ space

3) Penumpukan dengan sendiri nya memerlukan ruang yang berim plikasi kepada ruang PKL yang bertambah

4) Salah satu usaha menguasai ruang

5) Secara umum disemua kelas jalan, merupakan bentuk pertum buhan PKL dalam konteks spce yang digunakan

6) Bentuk usaha pengembangan PKL

Lebih jauh usaha PKL sebagai satu bidang kerja tersendiri, memacu dan memperkuat hasrtat untuk bertahan pada space yang dikuasainya. Selanjutnya memacu hasrat untuk pengembangan penguasaan terhadap space.

\section{Eskalasi Perubahan dari non permanen ke permanen}

Eskalasi kemampanan fisik wadah usaha PKL dari non permanen ke permanen diungkap dari fenomena pola penyebaran dan bentuk kios yang dipergunakan oleh PKL

\section{Pola Penempatan Dan Penyebaran Kios Pedagang Kaki Lima}

Berdasarkan karakteristik PKL terhadap variabel, dan faktor Pola Penempatan Dan Penyebaran Kios Pedagang Kaki Lima

Memberikan indikasi:

1) kuatnya kebersamaan PKL untuk sepakat dalam menguasai lahan

2) Implisit menyatakan terjadi penyebaran akibat peletakan ba rang dagang di kios

3) Ruang yang diguna kan tidak dapat di gilirkan, sehingga pelaku PKL terus membuka lahan baru

4) Usaha penyebaran PKL

5) pembenar an hidden power

Pola penempatan dan pola penyebaran menunjukan semakin kuatnya kecenderungan terjadinya aglomerasi kegiatan PKL, semakin kuatnya rasa kebersamaan sesama PKL dalam 
mempertahankan "hidden power" mereka atas lahan atau ruang kota yang mereka tempati

\section{Wadah PKL Sebagai Potensi Pembebanan Ruang}

Berdasarkan karakteristik PKL terhadap variabel, dan faktor Wadah PKL Sebagai Potensi Pembebanan Ruang Memberikan indikasi:

Penggunaan lokasi sebagai hunian (per manen) yang berimplikasi kepada pembebanan ruang.

Bentuk dari dimensi wadah usaha (kios) PKL yang menunjukan tanda-tanda tidak lagi sebagai sesuatu sekedarnya, tetapi merupakan sesuatu yang telah semakin berpotensi untuk membebani ruang jalan/ruang kota

\section{Krisis Ekonomi ke krisis lingkungan binaan perkotaan \\ Bertambahnya dan bergesernya} krisis secara horisontal dari krisis ekonomi hingga krisis lingkungan binaan di perkotaan, memerlukan antisipasi yang tidak pernah putus, karena tidak menutup kemungkinan lingkaran krisis itu merupakan garis iterasi yang tidak pernah berhenti.

\section{Indikator PKL Menjadi Profesi Yang Potensial Keluar Ekonom}

Berdasarkan karakteristik PKL terhadap variabel, dan faktor Menjadi Profesi Yang Potensial Keluar dari Krisis Ekonomi

Memberikan indikasi:

1) Penggunaan lokasi sebagai hunian (permanen) yang berimplikasi kepada pem bebanan ruang

2) Penggunaan lokasi sebagai hunian (permanen)

PKL Sebagai Alternatif Penghidupan Yang Layak Tidak Berbanding Lurus Dengan Peningkatan Kualitas
Lingkungan Binaan

Berdasarkan karakteristik PKL terhadap variabel, dan faktor PKL Sebagai
Alternatif Penghidupan Yang Layak Tidak Berbanding Lurus Dengan Peningkatan Kualitas Lingkungan Binaan Memberikan indikasi:

1) Perpindahan PKL ke lokasi lain merupakan potensi bagi kerusakan lingkung an binaan

2) Penempatan kios cenderung mengabaikan fungsi kesehatan lingkungan dalam konteks estetika

Usaha PKL sebagai wadah keluar dari krisis ekonomi telah diyakini. Namun harapan akan terwujudnya peningkatan taraf kehidupan disegala bidang masih menjadi pertanyaan besar, karena keluar dari krisis ekonomi saja tidak selalu berbanding lurus dengan peningkatan kualitas lingkungan binaan.

Pemahaman tentang tipomorpologi dan karakteristik ruang jalan atau ruang kota yang ditempati PKL, posisi penempatannya yang lazim dilakukan oleh PKL dan bentuk serta dimensinya beserta jenis barang dagangannya. Pemahaman tersebut dapat berguna bagi antisipasi krisis lingkungan binaan di masa depan dan berguna bagi uasaha pembenahan kondisi lingkungan binaan perkotaan, khususnya yang berkaitan dengan keberadaan PKL.

Secara sosiologis, kelompok PKL bersifat paguyuban (geimenschaft), artinya antara PKL yang satu dengan lainnya memiliki hubungan, baik keluarga, teman sedaerah maupun satu kelompok dari grosir mata dagangan (komoditas) yang sama. Sifat informalitas PKL dan juga label ilegal yang disandangnya, merupakan motif yang cukup kuat untuk membina hubungan baik antar anggota komunitas. Hal ini secara akomulatif menimbulkan perilaku politis PKL, sebagai sebuah sikap bersama untuk menyelesaikan permasalahan lisensi keberadaan PKL secara kolektif. Perilaku politis tersebut merupakan akumulasi hasil pengalaman kolektif yang berkulminasi dalam sangsi-sangsi yang selama ini diterima ketika PKL berhadapan dengan 
aparat pemerintah, pemilik toko serta masyarakat pengguna lainnya. Perilaku politis PKL tersebut menyebabkan transedensi dari survival (kegiatan PKL sebagai alternatif bagi masyarakat marginal keluar dari krisis ekonomi). Menjadi hidden power yang menjadikan PKL sebagai bidang kerja tersendiri yang banyak diminati dan terus berkembang. Kondisi ini praktis menimbulkan ekskalasi kegiatan dari non permanen menjadi permanen di lihat dari adanya aglomerasi kegiatan PKL dalam pola penempatan dan penyebaran PKL serta sarana berdagang yang tidak lagi sesuatu "sekedarnya". Evolusi ini dapat dikatakan sebagai imunisasi krisis ekonomi ke krisis lingkungan binaan yang membuat semakin sulit untuk membenahi keadaan.

Perilaku politis tersebut juga dilakukan oleh pihak luar PKL yang cenderung mempertahankan informalitas PKL, baik pemerintah maupun masyarakat. Perilaku politis yang bersifat memfasilitasi kegiatan PKL sekaligus melemahkan posisi PKL berupa pemberian kesempatan kepada PKL untuk melakukan "penyogokan" dan "penyuapan" kepada pemerintah melalui perantara seringkali dilakukan. Selain itu terjadi fenomena jual beli lapak yang dilakukan oleh makelar ataupun oknum pemerintah sendiri. Sementara kebutuhan dan kultur masyarakat yang menempatkan PKL sebagai tujuan utama kegiatan konsumsi dengan segala nilai tambah sebagai akibat informalitas PKL tersebut, semakin memperkuat eksistensi PKL. PKL juga menjadi format pedagang yang di incar oleh pedagang besar atau pengusaha sebagai bentuk penghidaran pajak. Oleh masyarakat, PKL dipertahankan informalitasnya. Hal ini dinilai dari fakta bahwa peningkatan kesejahteraan PKL tidak menjamin mekanisme penjualan dengan sarana berdagang berupa lapak di ruang publik ditinggalkan dan di ganti dengan kios formal. Kecenderungan PKL memanfaatkan ruang publik dan menggunakan lapak tersebut dimanfaatkan pula oleh oknum-oknum di lapangan dengan memfasilitasi pengadaan lapak. Kondisi kontradiktif di lapangan, dimanfaatkan secara produktif oleh masing-masing pelaku untuk mengedepankan kepentingan masingmasing. Hal ini menimbulkan sikap inkonsistensi, sehingga pemecahan masalah PKL semakin rumit akibat rawannya konflik. Dalam hal ini PKL merupakan satu-satunya pelaku yang berhadapan langsung dengan kepentingan dan keinginan pihak lain baik positip maupun negatif.

\section{KESIMPULAN}

Dengan

demikian dapat dikemukakan banyak yang berpengaruh terhadap kecenderungan perubahan paradigma. Bahwa "okupasi" pada lahan kosong (vacant land) di kota oleh masyarakat marjinal, pada awalnya merupakan usaha untuk survive, namun pada akhirnya menjadi power yang semakin sulit untuk dibenahi.

Keberadaan pedagang kaki lima, pertumbuhannya, kegiatannya dan kekuatan tersembunyi yang dimilikinya sangat signifikan berpengaruh terhadap kualitas lingkungan binaan. Estetika kota, dan pembangunan kota dimasa mendatang. Kenyataan manunjukan bahwa keberhasilan melewati krisis ekonomi tidak selalu berbanding lurus dengan peningkatan kualitas lingkungan binaan.

\section{REKOMENDASI}

Usaha preventif sebelum dilakukan usaha pembenahan, perlu dicermati tentang perubahan paradigma tentang PKL. Selain itu perlu juga dicermati pula konsep tentang masyarakat marjinal yang berkaitan dengan usaha PKL yang dalam hal ini memerlukan redifinisi. Merupakan tantangan yang sangat besar bagi semua pihak yang berkepentingan dengan pembenahan lingkungan binaan dalam membiat persepsi tentang kemiskinan dan kemapanan di perkotaan. Dikawatirkan akan tidak dapat mencapai sasaran. 
Sudah menjadi fakta bahwa PKL adalah sesuatu yang sangat fenomental. Hendaknya harus ada pengaturan formal baik dalam Rencana Tata Ruang sebagai kebijakan, mengingat usaha PKL sifatnya sudah menjadi bidang pekerjaan tersendiri walaupun selama ini diberi label "informal", dan mengingat usaha PKL menempati bagian kota yang secara visual mencolok mata dan secara spatial berada di tempat yang strategis dan bernilai lahan tinggi. Hal ini penting menjadi pertimbangan dan memerlukan usaha pemilahan yang tepat antara kemiskinan semu dengan kemiskinan nyata.

Perlu mendudukan secara benar fungsi ruang jalan, apakah hanya sebagai rng publik, dimana hak pablik sepenuhnya adalah sesuai dengan peruntukan sebuah ruang jalan atau bagian ruang kota lain yang berfungsi sebagaimana peruntukannya atau ditetapkan saja sebagai ruang kota yang berfungsi ganda. Dengan demikian perlu dicermati kembali konsep keadilan keseimbangan anta kepentingan publik (umum) dengan kepentingan privat (individu) dalam haknya masing-masing terhadap ruang publik kota.

Pembenahan fisik (apalagi bila hanya dari sisi penataan estetika semata) tidak akan berjalan bila pembenahan pada aspek lain tidak sejalan. Untuk itu diperlukan selain masukan fisik arsitektural, jua aturan main yang jelas, berupa peraturan pengelolaan, pemanfaatan dan pemeliharaan ruang jalan secara benar dan adil bagi semua pihak. Hal itu penting, agar ruang jalan tidak menjadi seolah-olah etalase kemiskinan sebiah kota. Paling tidak, kemiskinan tentang pemahaman mengenai kemiskinan itu sendiri.

\section{DAFTAR PUSATAKA}

Denzin, Norman K. and Lincoln, Yvonna S. (1994), Handbook of Qualitative Research. Sage Publications Press, Thousand Oaks London.
Geertz, C (1989), Penjaja dan Raja : Perubahan Sosial dan Modernisasi Ekonomi di Dua Kota Indonesia. Yayasan Obor, Jakarta

Hidayat (1978), Pengembangan Sektor Informal dalam Pembangunan Nasional : Masalah dan Prospek, Pusat Penelitian Ekonomi dan SDM FE. Univ. Pajajaran, Bandung.

Jones, Gavin (1975), The Problem of Urbanisation in Indonesia, Jakarta.

Koentjaraningrat (1993), Metode-Metode Penelitian Masyarakat.

Gramedia, Ja-karta.

Miles, Matthew and Huberman, Michael (1992), Analisis Data Kualitatif. Universitas Indonesia Press, Jakarta.

Mikkelsen, Britha (1999), Metode Penelitian Partisipatoris Dan Upaya-Upaya Pemberdayaan. Yayasan Obor Indonesia, Jakarta.

Moleong, Lexy (2001), Metodologi Penelitian Kualitatif. PT. Remaja

Rosda-karya, Bandung.

Nasution (2003), Metode Research. PT. Bumi Aksara, Jakarta.

Noeng Muhadjir (1989), Metodologi Penelitian Kualitatif. Rake Sarasin, Yogyakarta.

Patton, Michael (1990), Qualitative Evaluation and Research Methods. Sage Publication Press, California,

Singarimbun, Masri (1989), Metode Penelitian Survai. LP3ES, Jakarta.

Saul M. Katz (1975). A Systems Approach to Development Adminitration. American Society for Public Administration. Washington D.C. Soewarno, Urip (1978), Migrasi dan Kesempatan Kerja dalam Hubungannya dengan Sektor Informal pada beberapa kora di Jawa, kertas kerjas IPADI, Bandung. 
Usman, Husaini (2001), Metodologi Penelitian Sosial. PT. Bumi Aksara, Jakarta.

Wirosardjono, Soetjipto (1981), Masalah Tenaga Kerja di Sektor Informal, Jakarta 